\title{
Hyperalphalipoproteinemia and Beyond: The Role of HDL in Cardiovascular Diseases
}

\author{
Antonina Giammanco ${ }^{1,+}$, Davide Noto ${ }^{1,+}$, Carlo Maria Barbagallo ${ }^{1,+}{ }^{\dagger}$ Emilio Nardi ${ }^{1}$ (D) Rosalia Caldarella $^{2}$, \\ Marcello Ciaccio ${ }^{2,3}$ (D) $^{\text {Maurizio Rocco Averna }}{ }^{1}$ (D) and Angelo Baldassare Cefalù 1,*
}

1 Department of Health Promotion, Mother and Child Care, Internal Medicine and Medical Specialties-University of Palermo, Via del Vespro, 129, 90127 Palermo, Italy; agiamman@gmail.com (A.G.); notoddd@gmail.com (D.N.); carlo.barbagallo@unipa.it (C.M.B.); emilio.nardi@unipa.it (E.N.); maurizio.averna@unipa.it (M.R.A.)

2 Department of Laboratory Medicine, Unit of Laboratory Medicine CoreLab, University Hospital “P. Giaccone”, 90127 Palermo, Italy; rosalia.caldarella@policlinico.pa.it (R.C.); marcello.ciaccio@unipa.it (M.C.)

3 Department of Biomedicine, Neurosciences and Advanced Diagnostics, University of Palermo, 90127 Palermo, Italy

* Correspondence: abaldassare.cefalu@unipa.it

+ These Authors equally contributed to the manuscript.

Citation: Giammanco, A.; Noto, D.; Barbagallo, C.M.; Nardi, E.;

Caldarella, R.; Ciaccio, M.; Averna, M.R.; Cefalù, A.B.

Hyperalphalipoproteinemia and Beyond: The Role of HDL in Cardiovascular Diseases. Life 2021, 11, 581. https://doi.org/10.3390/life 11060581

Academic Editors: Michael Russell, Dirk Schulze-Makuch, Michael W.

Friedrich, Kousuke Hanada, Stefanos Roumeliotis, Hiroki Nishikawa and Alfredo Conti

Received: 19 May 2021

Accepted: 16 June 2021

Published: 18 June 2021

Publisher's Note: MDPI stays neutral with regard to jurisdictional claims in published maps and institutional affiliations.

Copyright: (c) 2021 by the authors. Licensee MDPI, Basel, Switzerland. This article is an open access article distributed under the terms and conditions of the Creative Commons Attribution (CC BY) license (https:/ / creativecommons.org/licenses/by/ $4.0 /)$.
Abstract: Hyperalphalipoproteinemia (HALP) is a lipid disorder characterized by elevated plasma high-density lipoprotein cholesterol (HDL-C) levels above the 90th percentile of the distribution of HDL-C values in the general population. Secondary non-genetic factors such as drugs, pregnancy, alcohol intake, and liver diseases might induce HDL increases. Primary forms of HALP are caused by mutations in the genes coding for cholesteryl ester transfer protein (CETP), hepatic lipase (HL), apolipoprotein C-III (apo C-III), scavenger receptor class B type I (SR-BI) and endothelial lipase (EL). However, in the last decades, genome-wide association studies (GWAS) have also suggested a polygenic inheritance of hyperalphalipoproteinemia. Epidemiological studies have suggested that HDL-C is inversely correlated with cardiovascular (CV) risk, but recent Mendelian randomization data have shown a lack of atheroprotective causal effects of HDL-C. This review will focus on primary forms of HALP, the role of polygenic inheritance on HDL-C, associated risk for cardiovascular diseases and possible treatment options.

Keywords: hyperalphalipoproteinemia; HDL; CETP; polymorphisms; cardiovascular disease

\section{Introduction}

Hyperalphalipoproteinemia (HALP) is a condition characterized by elevated plasma high-density lipoprotein cholesterol (HDL-C) levels > 90th percentile of the distribution of HDL-C values in the general population [1], associated or not with overt clinical manifestations and predisposition to atherosclerotic coronary artery disease (CAD) [2]. Plasma total cholesterol (TC) levels may be increased, while very low-density lipoproteins (VLDL) and low-density lipoproteins (LDL) are often in the normal range. HALP is classified as moderate (HDL-C levels between 80 and $100 \mathrm{mg} / \mathrm{dl}$ ) and severe (HDL-C levels > $100 \mathrm{mg} / \mathrm{dl}$ ) [2]. HALP is the hallmark of primary hyperalphalipoproteinemia, a heterogeneous genetic lipoprotein disorder, usually transmitted as a co-dominant trait, due to mutations in known candidate genes or to other genes yet to be identified ("orphan" primary HALP). Mutations in the genes coding for cholesteryl ester transfer protein (CETP), hepatic lipase (LIPC), and apolipoprotein C-III (APOC3) are known causes of primary HALP [1]. The pathophysiology of other forms of HALP is not well characterized, and it is still unknown if the increased production or reduced catabolism of HDL are the cause of this lipid disorder [1]. Epidemiological studies have demonstrated a strong inverse relationship between low HDL-C levels and risk for developing atherosclerotic cardiovascular disease (ASCVD) $[3,4]$. On the other hand, Mendelian randomization studies have failed in demonstrating a causal 
relationship between HDL-C and ASCVD [5]. Low plasma HDL-C levels strongly correlate with high $\mathrm{CV}$ risk, but genetically determined low HDL-C levels are not associated with an increased risk for ASCVD, suggesting that low HDL-C levels per se are not a cause of cardiovascular diseases [5,6]. Epidemiological studies have shown contradictory results on the relationship between high HDL levels and CV risk in subjects with primary HALP $[7,8]$. Several mechanisms may play a role in explaining this phenomenon, including HDL function in reverse cholesterol transport (RCT) [9]. Besides the major involvement in RCT, HDLs exert several anti-inflammatory effects that may prevent endothelial dysfunction [10], which is considered one of the first events in atherogenesis [11].

\section{HDLs Physiology}

HDLs are characterized by a heterogenous sub-population of lipoprotein particles, which undergo remodeling and transformation processes mediated by several plasma enzymes and transcription factors [12]. The main HDL-associated apolipoprotein is apolipoprotein AI (apoA-I), a protein of 243 amino acids [13] which is synthesized by the liver and intestine and represents the principal structural component of HDLs. Schematic representation of the biogenesis of HDL is illustrated in Figure 1. HDL particles are involved in the so-called "reverse cholesterol transport (RCT)", a pivotal pathway involved in the return of excess cholesterol from peripheral tissues to the liver for excretion in the bile and eventually in the feces. RCT from macrophages in atherosclerotic plaques (macrophage RCT) is a critical mechanism of the antiatherogenicity of high-density lipoproteins (HDLs) (Figure 2) [14-20]. Besides their major role in promoting cell cholesterol efflux and reverse cholesterol transport, HDLs may exert atheroprotective activity by preventing endothelial dysfunction [10], a key step in the development of atherosclerosis. HDL downregulates cytokine-induced expression of cell adhesion molecules (CAMs) [10] and increases endothelial nitric oxide synthase (eNOS) expression and activation [21], NO release, and bioavailability [22]. HDLs induce the production of $\mathrm{NO}$ by increasing the endothelial nitric oxide synthase (eNOS) activity, thus improving the endothelial function [23,24]. Besides the antioxidative properties of apoA-I, the HDL accessory protein-paraoxonase 1 (PON1) - may exert an important role in determining the antioxidative capacity of HDL particles, and is implicated in reverse cholesterol transport and atheroprotective effects [25]. In addition, HDLs together with ABCA1 and ABCG1 may play an anti-atherogenic role by inhibiting hematopoietic stem cell (HSC) proliferation and suppressing macrophage activation, thus decreasing inflammatory responses [26].

Although in this review we will mainly focus on the primary familial causes of HALP, it is worth mentioning that several conditions are known to be associated with elevated HDL-C levels. Patients with secondary HALP tend to be asymptomatic, aside from some rare reported cases of juvenile or premature corneal opacities [27] or multiple symmetric lipomatosis [28], and are characterized by high levels of HDL-C and a low incidence of CVD [29]. Lifestyle factors include vigorous and sustained aerobic exercise, regular and substantial alcohol consumption, and weight loss, and the increase in HDL-C levels may be mainly attributed to CETP and/or HL inhibition [30-32]. HDL-C levels are known to be higher in women than in men, and estrogens play an important role in this phenomenon [30,33]. In users of combination oral contraceptives, the rising effect of estrogen is partly counter-regulated by the presence of added progestin such levonorgestrel, which exerts an androgenic effect by decreasing the Apo-AI synthesis and increasing LPL activity [34]. In uncomplicated pregnancy, especially over the second and third trimester, women may exhibit an increase in HDL-C levels due to a reduction in CETP activity (33). The liver is one of the main sites for HDL catabolism [35], and in some chronic conditions, such as biliary cirrhosis, HDLs may accumulate in the bloodstream because of a defect in their catabolism giving rise to secondary HALP [35]. Several classes of commonly used drugs in clinical practice exert effects both on HDL levels and functions through various mechanisms. Among them are anti-inflammatory medication (NSAIDs, corticosteroids, 
methotrexate, sulfasalazine, hydroxychloroquine or biologics) [36-38] and lipid-lowering drugs (statins, fibrates, and niacin) [39].

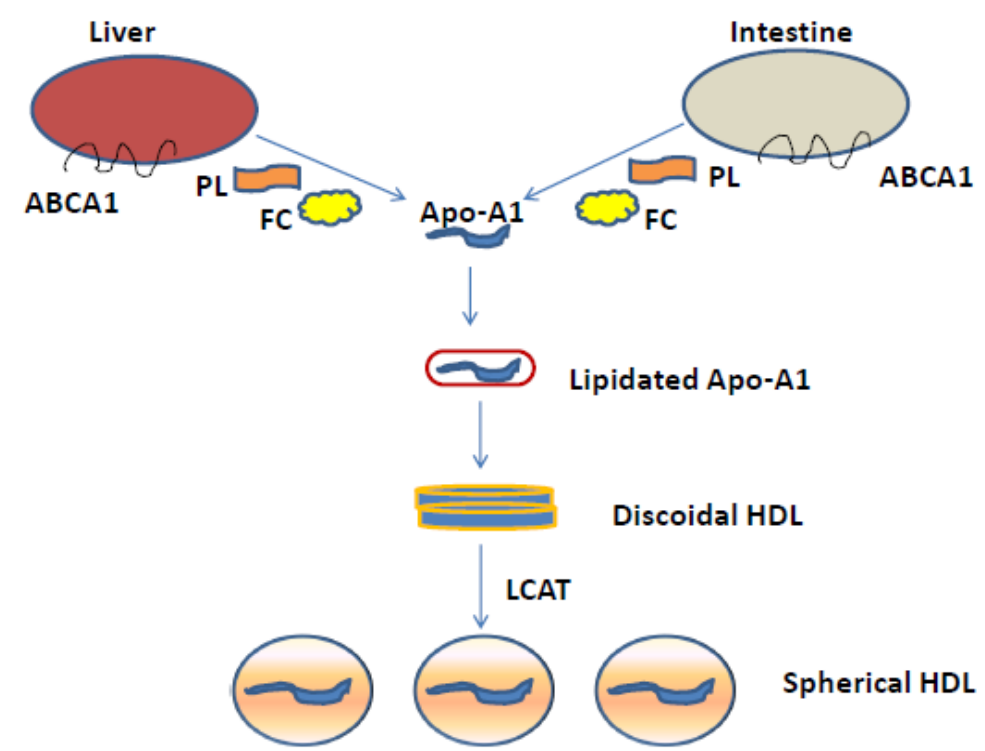

Figure 1. Schematic representation of the biogenesis of HDL. The first step in HDL biogenesis begins with the secretion of Apo-A1 by the liver and the intestine. The lipid-poor Apo-A1 then interacts with ABCA1 and progressively gains phospholipids (PL) and free cholesterol (FC) from the cells. The lipidated apoA-I is gradually converted to discoidal particles composed of unesterified cholesterol. Then, the enzyme lecithin/cholesterol acyltransferase (LCAT) esterifies the FC and the discoidal HDLs are finally converted to spherical HDL particles containing Apo-A1, Apo-E or Apo-A4: secondary causes of hyperalphalipoproteinemia.

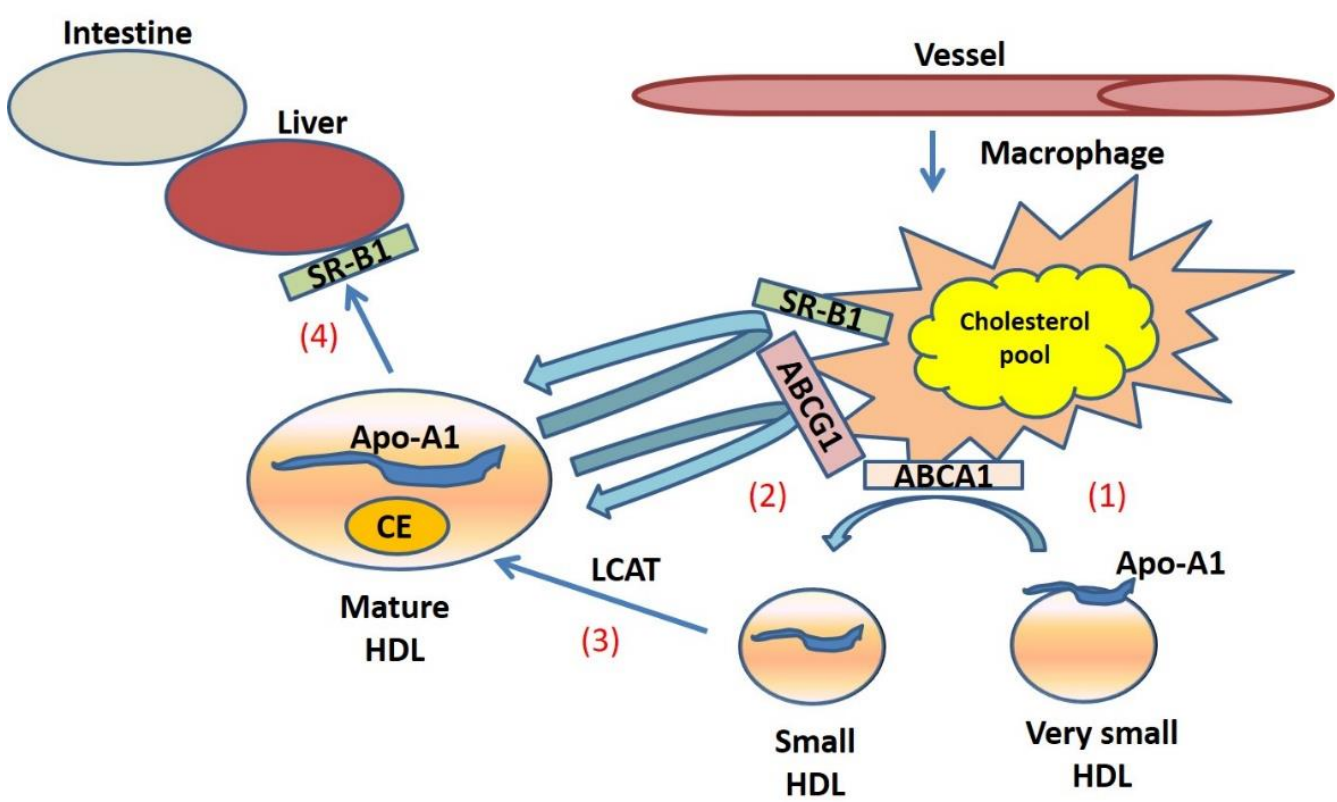

Figure 2. Schematic representation of the Reverse Cholesterol Transport (RCT) mechanism. In the RCT process, the ApoA-I receives the cholesterol from the foam cells (macrophages) through the ATPbinding cassette transporter member 1 (ABCA1) (1), leading HDL to become mature in a mechanism mediated by the transporter ABCG1 (2). The Lecitin:cholesterol acyltransferase (LCAT) (3) esterifies the free cholesterol (FC) thus contributing to form mature and spherical HDLs formed of a cholesteryl ester (CE) core. Finally, HDLs bind to the scavenger receptor class B type-1 (SR-B1) in the liver (4) and are selectively removed from the blood stream. 


\section{Primary Causes of HALP \\ 3.1. CETP Deficiency}

The CETP gene maps on the long arm of chromosome 16 (16q12-16q21); it comprises 16 exons [40] and encodes for a glycosilated plasma protein which catalyze the exchange of triglycerides (TGs) and cholesteryl esters (CEs) among lipoprotein particle cores [41,42]. In more detail, it mediates the transport of CE from HDL to VLDL/chylomicrons and TG from VLDL/chylomicrons to HDL and low-density lipoproteins (LDL) [41,43], thus regulating HDL-C plasma levels. The genetic epidemiology of HALP is mostly based on studies performed in Japan, the country with the highest known prevalence of primary HALP and where CETP deficiency was first described in 1985 [44-46]. Since then, several cases of CETP deficiency due to mutations of the CETP gene have been reported in the Japanese population, and it has been shown that in subjects with moderate and severe HALP, the prevalence of CETP deficiency is $\sim 60 \%$ and $\sim 31 \%$, respectively [47,48]. According to Japanese epidemiological data, $27.6 \%$ of Japanese subjects with HDL cholesterol $>60 \mathrm{mg} / \mathrm{dl}$, and $31.4-32.5 \%$ of those with HDL-cholesterol $>80 \mathrm{mg} / \mathrm{dl}$ are carriers of CETP gene mutations [49]. Three CETP gene mutations account for most cases among the Japanese: intron $14 \mathrm{G}(+1)>\mathrm{A}(\mathrm{Int} 14 \mathrm{~A})$ splicing defect (1-2\%), exon 15 missense mutation (D442G) (14) $(6-7 \%)$ and the nonsense mutation G309X [50,51]. CETP deficiency is quite common in other Asian populations (mostly Chinese, Siberians and Thai) [52], and with this observation a founders' effect might be hypothesized [52]. However, this genetic defect is rare in other ethnic groups, even though some studies have reported sporadic cases of CETP deficiency in the United States [53], Italy, Greece and the Netherlands [54-57]. Resequencing of the CETP gene in White Americans and Black Africans allowed the identification of rare variants (allele frequency $<0.01$ ), which may explain the extremely high HDL-C phenotype in both groups [58]. The loss-of-function CETP protein results in significantly elevated HDL-C levels in homozygotes (usually $>100 \mathrm{mg} / \mathrm{dL}$ ), in whom CETP mass and/or activity is not detectable in plasma [33,47] and moderately elevated HDL-C levels in heterozygotes with a CETP mass half of that compared to healthy controls [33,47]. The lack of CETP activity is responsible for the accumulation of CE in HDLs that becomes larger $(>11 \mathrm{~nm})$; on the other hand, LDL-C levels tend to be low and LDL particles are rich in triglycerides and polydisperse with a subpopulation of small LDLs $[1,2,45,48,59,60]$. Moreover, in CETPdeficient subjects, HDL size correlates inversely with the CETP mass and activity, and HDLs are larger not only in normal subjects but also in patients with other forms of HALP [61]. This key biochemical feature in CETP deficiency influences HDL functional properties and may help to discriminate the CETP deficiency from other genetic causes of HALP $[62,63]$. In addition, the LDL particles in CETP deficiency [60] are compositionally altered and display a low affinity for LDL receptor and may be atherogenic [60]. Plasma apolipoproteins AI, CIII and E are increased while apoB is normal or decreased [63]. Even though CETP deficiency is associated with high HDL-C and decreased LDL-C, its role in atherosclerotic cardiovascular diseases has been controversial. In an early observation by Inazu et al., 10 subjects with very HDL-C levels due to complete CETP deficiency, belonging to five unrelated families, did not have any premature atherosclerotic diseases, and two families displayed a trend toward longevity [64]. In the Honolulu Heart Program, 3469 Japanese male subjects, carriers of two different CETP gene mutations, were evaluated for correlations between CETP deficiency, HDL-C levels and cardiovascular diseases [7]. It was found that male heterozygous carriers of CETP gene mutations with low or slightly increased HDL-C levels $(1.0-1.6 \mathrm{mmol} / \mathrm{L})$ exhibited a higher cardiovascular risk than non-carriers matched for gender and HDL-C levels [7]. On the other hand, males with considerably elevated HDL-C levels $(>1.6 \mathrm{mmol} / \mathrm{L})$, regardless of the CETP gene status, had a low frequency of cardiovascular disease (coronary heart disease) [7]. Furthermore, analysis of cardiovascular outcomes in a Japanese cohort of 19,044 males and 29,487 females showed that subjects with both markedly elevated and mild-to-moderate HDL-C levels experienced fewer cardiovascular diseases independently of the status of the CETP gene mutation carrier [65]. To date, the correlation between CETP and cardiovascular diseases 
is still controversial, as is its role on longer life expectancy. Further studies are needed to clarify these observations $[66,67]$.

\subsection{Hepatic Lipase and APO-CIII Deficiency}

HL deficiency is another cause of monogenic HALP. Hepatic lipase (HL) is a heparansulfate proteoglycan (HSPG)-bound lipolytic enzyme synthesized and secreted by hepatocytes. It is encoded by the LIPC gene mapping on chromosome 15 [68], and it is involved in HDL and triglyceride metabolism [69-74]. Single-nucleotide polymorphisms (SNPs) of LIPC may be pro-atherogenic, whereas others induce an anti-atherogenic phenotype $[69,75,76]$. This different role of LIPC SNPs is influenced by secondary influences such as environmental, lifestyle and hormonal factors [77]. HL deficiency may increase the HDL size and their functions in the RCT process, thus increasing the risk of premature cardiovascular diseases [72]. To date, only a few case reports of families with primary HALP caused by a genetically defined HL deficiency have been described [78-82]. Polymorphisms in the HL gene promoter act as modifiers of HDL-C levels, but the moderate increase in HDL induced by these polymorphisms cannot explain the high HDL levels observed in primary HALP. APO-CIII. Apolipoprotein CIII (Apo-CIII) is a small apolipoprotein synthesized mainly in the liver and regulates plasma TG homeostasis by inhibiting lipoprotein lipase (LPL) activity [83]. Apo-CIII plays an important role in HDL metabolism as well as in TG physiology. Loss of function of APO-CIII gene mutation carriers exhibits 39\% lower plasma TG levels, 22\% higher plasma HDL-C levels, 16\% lower plasma LDL-C levels, and reduction in CVD risk [84,85]. Two novel loss-of-function mutations which affect the splice site of the APOC3 gene (c.13-2A > G and c.55+1G > A) have been identified and associated with plasma HDL-C levels above the 95th percentile and an atheroprotective lipid profile [86]. A missense APOCIII variant (Lys58 > Glu) in heterozygosity was described in two women with hyperalphalipoproteinemia [87].

\subsection{Scavenger Receptor Class B Type I (SR-BI)}

The scavenger receptor class B type I (SR-BI), encoded by the SCARB1 gene, is primarily expressed in the steroidogenic tissues and in the liver, where it acts as an important receptor for HDLs and controls selective uptake of the cholesterol esters by HDL [88]. SR-BI is involved in the bi-directional transfer of esterified cholesterol between cells and HDL [89]. SR-BI knock-out mice exhibited a twofold increase in HDL-C plasma levels, accelerated atherosclerosis, impairment of liver cholesterol transfer [90], and adrenal glucocorticoidmediated stress response [91]. SCARB1 rare point mutations associated with a decreased SR-BI protein expression and function have been identified in subjects with high plasma HDL-C levels in humans [92-94]. However, despite the high plasma HDL-C concentration, carriers exhibit an increased risk of CVD due to the impaired RCT pathway caused by the reduced hepatic SR-BI function [95-97]. Carriers of the P376L mutation have been shown to have a $79 \%$ higher risk of $\mathrm{CHD}$, as compared to non-carriers. Vergeer M. et al. resequenced SCARB1 genes in subjects with high HDL-C levels $(>70.4 \mathrm{mg} / \mathrm{dl}$ to $1.8 \mathrm{mmol} / \mathrm{L})$ and identified a family carrying the missense mutation P297S, which co-segregated with high HDL-C levels, decreased the cholesterol efflux from macrophages, increased platelet dysfunction, and reduced adrenal steroidogenesis [94], although without significant impact on atherosclerosis [94]. Yang X. et al. have described the association of SCARB1 variants resulting in a decreased function of SR-B1 in the binding/intracellular transport of Lp(a) associated with a peculiar, combined lipid phenotype characterized by elevated HDL-C and $\mathrm{Lp}(\mathrm{a})$ levels [98].

\subsection{Endothelial Lipase (EL)}

Endothelial lipase (EL) is mostly involved in HDL phospholipid hydrolysis [99] through a mechanism independent from the dissociation of lipid-free/lipid-poor apoAI [100]. EL is coded by the LIPG gene and it is expressed mainly in endothelial cells [99], but also in other several tissues including the liver, lungs, placenta, thyroid, kidney, and 
macrophages [99]. EL, together with hepatic lipase (HL), exerts a negative regulation in HDL metabolism and modulates the cholesterol efflux capacity (CEC) of serum and isolated HDL [101,102]. Experiments in EL and HL knock-out mice have shown that these two lipases affect the RCT process and promote the HDL antioxidant properties [102]. Carriers of loss-of-function variants of EL have a reduced lipolytic activity [103] and a lipid phenotype characterized by an increase in HDL-C plasma levels with large HDL particles $[100,101,104]$. Further studies are needed to evaluate the role of loss-of-function variants and if reduced EL activity might be cardioprotective [105].

\subsection{Polygenic Causes of Hyperalphalipoproteinemia}

Several polymorphisms of the CETP gene with a reduction in CETP activity have been associated with HDL-C levels in the general population [106]. TaqIB is a silent base change affecting a nucleotide at position 277 on the first intron of the CETP gene and represents a common polymorphism associated to increased HDL cholesterol plasma levels and to a slight reduction in cardiovascular risk [107]. Some CETP genotypes correlate with a mild reduction in CETP activity, a marginal HDL-C increase, and an inverse association with coronary artery disease [108]. The variation in CETP activity is much better explained by using a haplotype model consisting of TaqIB and four other polymorphisms in the CETP gene [109]. Different studies (the Framingham Offspring Study, the Veterans Affair HDL-c Intervention Trial and the WOSCOPS) have confirmed the association of CETP and a low CV risk in males [110-112], as has the AtheroGene Study, which, by evaluating 1211 patients with coronary artery disease (CAD) on follow-up, has demonstrated an association of the A allele of the CETP-629 variant with a reduced CV lethality [113]. Another haplotype analysis demonstrated a correlation between the -2505 CETP variant and HDL metabolism and CV risk [114]. Interestingly, a study performed in southern China (Hainan) has shown a correlation between CETP polymorphisms and longevity: TaqIB and the variant I405V were combined and analyzed in a group of centenarians matched with controls [115], and it was found that the alleles B1 and V contributed to a protective role on longevity in this cohort of subjects. In the last decade, genome-wide association studies (GWAS) have suggested a more complex polygenic inheritance of HDL plasma levels [116]. Beside the known candidate genes of primary HALP, other genes (such APOA1, LCAT, APOA4, APOE, PLTP and PON1) involved in HDL metabolism have been reported to modulate HDL-C plasma levels [117-119]. Although several genes have been discovered to be associated with HDL metabolism, to date, only a small percentage of this genetic variability can be explained and their effects on HDL phenotypes should be further investigated and probably related to environmental factors [120,121]. Further genetic variants will be identified; therefore, it will be possible to predict, through an allelic risk score, subjects at high cardiovascular risk and possible strategies for prevention [122].

\subsection{HALP and Cardiovascular Risk}

Following the seminal data provided by Gofman J.W. et al. [123] and the Framingham study [124], several studies have confirmed the inverse relationship between HDL-C plasma levels and coronary heart disease (CHD), suggesting an atheroprotective role of HDLs [125-127]. Furthermore, some studies have reported a positive correlation between elevated HDL-C and longevity [128]. The Long-Life Family Study (LLFS) has demonstrated that subjects with high HDL-C are healthier in terms of CV outcomes [129]; a study on aging male veterans revealed that elevated HDL-C correlates with longer life expectancy [128]. However, recent findings provided by Mendelian randomization studies support the hypothesis that some genetic mechanisms that raise plasma HDL cholesterol do not seem to lower risk of myocardial infarction $[5,6]$. These data may question the concept that HALP and/or the pharmacological raising of plasma HDL cholesterol will translate into atheroprotection and a reduction in risk of myocardial infarction [130]. For example, in statin clinical trials, ApoAI was inversely related to low CV risk, whereas HDL-C was not [131]. In addition, in the JUPITER trial of treatment with the high-intensity statin 
rosuvastatin, HDL-C was not a predictive factor of residual CV risk [132]. In LDL receptor KO mice, naturally lacking CETP, the expression and overexpression of CETP led to an atherogenic phenotype [133]. On the other hand, inhibition of CETP activity in rabbits leads to a condition mimicking the human primary HALP due to CETP deficiency with a striking HDL increase (about 90\%) and antiatherogenic effects. Targeting the SR-B1 gene in mice increases HDL-C levels but is associated with accelerated atherosclerosis [133]. In brief, in animal models, the targeting of different HDL metabolism-related genes produces the same HDL-C increase but may induce atherogenic or atheroprotective effects based on the metabolic scenario and on the role that the different genes play in the specific biochemical pathway. In humans, HALP due to CETP deficiency represents a unique setting in which the high HDL-C and cardiovascular disease relationship has been studied. In Japan, CETPdeficient patients with HDL-C levels $>80 \mathrm{mg} / \mathrm{dl}$ do not seem to be protected against atherosclerotic vascular disease [7]. A recent hypothesis raised the focus on a dysfunctional RCT process which might increase the plasma HDL-free cholesterol (HDL-FC) level [16]. Thus, HDL-FC levels may represent a valuable biomarker independent of HDL-cholesteryl ester (HDL-CE and TC to assess cardiovascular risk, progression of ASCVD and response to lipid lowering treatments). HALP subjects exhibit higher levels of HDL-FC, and the plasma efflux capacity is lower than in those with normal HDL-C [16]. This process, which regulates FC bioavailability, could exert potentially toxic and pro-atherogenic properties on several tissues, including the artery wall, thus increasing the risk of atherosclerosis [16]. The RCT model was supported by several large studies which have revealed an inverse correlation between macrophage cholesterol efflux to plasma HDL and ASCVD [18]. In the Copenhagen City Heart Study and in the Copenhagen General Population Study, two large prospective population-based studies, a U-shaped association between HDL plasma levels and overall and cardiovascular mortality has been observed in both males and females, with a more pronounced risk of all-cause mortality in men [134,135]. The lowest frequency of CV events was observed for HDL-C levels close to $58 \mathrm{mg} / \mathrm{dl}(1.5 \mathrm{mmol} / \mathrm{L})$ for men and $77 \mathrm{mg} / \mathrm{dl}(2.0 \mathrm{mmol} / \mathrm{L})$ for women, and no further CV protection was evidenced with HDLC plasma levels higher than these cut-offs [134]. Moreover, in the Copenhagen City Heart Study, it was demonstrated that two CETP polymorphisms were correlated with a reduced cardiovascular risk as well as longevity [136]. Similarly, in the CANHEART (Cardiovascular Health in Ambulatory Care Research Team) study [137] and in the study by Bowe et al. [138], increases in CV disease at HDL-C levels $>90 \mathrm{mg} / \mathrm{dl}(2.3 \mathrm{mmol} / \mathrm{L})$ and $>90$ th percentile, respectively, were associated with increased hazard risk for mortality [138]. In summary, low HDL-C remains a significant factor for increased disease risk, whereas high HDL-C levels are not associated with cardioprotection, and this should prompt a re-evaluation of high HDL-C cutoffs in CVD risk calculations $[136,137]$. It has been hypothesized that this paradox could be the result of larger and dysfunctional HDL particles that might remain entrapped in the arterial intima, thus promoting cholesterol deposition and atherosclerosis progression in subjects with extremely high HDL-C levels [139].

\subsection{Pharmacological Targets to Increase HDL-C}

The concept that targeting HDL-C may be advantageous in terms of $\mathrm{CV}$ risk reduction has been taken into consideration for decades as an important treatment strategy. Niacin is a potent HDL-C-raising drug, seemingly an attractive approach to reduce cardiac events in patients with or at risk of atherosclerotic cardiovascular disease [140]. However, over the years, several clinical trials have failed to demonstrate benefits in terms of cardiovascular endpoints [141-145]. Table 1 shows a schematic view of the major niacin-based trials and their effects on HDL-C and on CV outcomes [144-153]. Fibrates have been used over the years to increase HDL-C, and their effects were evaluated in several clinical trials (the most representative are the FIELD—Fenofibrate Intervention and Event Lowering in Diabetes; ACCORD-Action to Control Cardiovascular Risk in Diabetes; VA-HIT-Veterans Administration HDL Intervention Trial, and the HHS-Helsinki Heart Study), although have failed in showing a significant CV risk decrease despite an HDL-C increase [142]. Statins 
have shown a consistent effect on HDL-C increases, and several trials have demonstrated this property. Among these, the VOYAGER study has evaluated the role of rosuvastatin (5-40 mg), atorvastatin (10-80 mg) and simvastatin (10-80 mg) in HDL-C increases, which were elevated as well associated with LDL-C decreases [154].

Table 1. Major niacin-based trials and their effects on HDL-C and on CV risk.

\begin{tabular}{|c|c|c|c|}
\hline Clinical Trial & Description & Effect on HDL-C and CV Outcomes & Reference \\
\hline AIM-HIGH & $\begin{array}{c}3414 \text { subjects were treated with niacin or } \\
\text { placebo on top of high-intensity } \\
\text { statin treatment }\end{array}$ & $\begin{array}{l}\text { The niacin-treated arm showed a modest but } \\
\text { significant HDL-C increase ( } 25 \% \text { vs. } 12 \%) \text { but } \\
\text { no benefits in terms of cardiovascular } \\
\text { outcomes. The trial was stopped earlier } \\
\text { due to futility of results. }\end{array}$ & {$[144]$} \\
\hline
\end{tabular}

25673 subjects affected by vascular diseases were randomized to receive extended-release niacin + laropiprant (to reduce the flushing side-effect of niacin) or placebo both on top of statin therapy

HPS2-THRIVE

Males with metabolic syndrome (obese, Niacin Study Group hypertriglyceridemic, non-diabetic) and low HDL-C levels received niacin for 8 weeks

8341 Males after myocardial infarction

Coronary Drug treated with niacin or clofibrate vs. placebo

Project (CDP) were treated with ER-niacin $1 \mathrm{~g} /$ day vs. placebo on top of stable statin therapy

ARBITER-2

208 patients ( $\geq 30$ years) with CAD or equivalent of $C A D$ risk were treated with

ER-niacin vs. ezetimibe on top of

ARBITER-6

$$
\begin{array}{r}
\text { ER-niacin vs. ezetimibe } \\
\text { statin therapy }
\end{array}
$$

143 patients ( $<76$ years) with low HDL-C and coronary disease were treated with Niacin 0.25-3 g gemfibrozil $1.2 \mathrm{~g}$ cholestyramine $2 \mathrm{~g}$ vs. placebo

AFREGS

162 Males after CABG treated with Niacin 3-12 g/day + colestipol 30 g/day vs. placebo
167 patients with Coronary Artery Disease
558 patients after MI, aged $<70$ treated with Clofibrate $2 \times 1 \mathrm{~g}+$ niacin $3 \times 1 \mathrm{~g}$ vs. placebo
After a follow up mean of 3.9 year, the niacin-treated group showed a modest but significant HDL-C increase $(6 \mathrm{mg} / \mathrm{dl})$, but no difference in the incidence of $\mathrm{CV}$ events.

A decrease in LDL-C and total cholesterol associated to a reduction in inflammation, cell-adhesion and proliferation biomarkers.

No significant change of $\mathrm{CV}$ events.

HDL-C increase, LDL-C and TG decrease. No significant change of $\mathrm{CV}$ events.

HDL-C increase by $21 \%$. Progression of cIMT in the niacin group

HDL-C increase in ER-Niacin group; reduced incidence of cardiovascular events by $5 \%$ in ER-Niacin group vs. $1 \%$ in EZE-group

HDL-C increase by $36 \% ; 13.7 \%$ decrease of combined cardiovascular events. No significant data.

HDL-C increase by 31\%; TC decrease by $15-20 \%$ and LDL-C decrease by $43 \%$; atherosclerotic regression in $16.2 \%$ of patients at 2 years and $17.9 \%$ at 4 years, compared with $2.4 \%$ and $6.4 \%$, respectively, in the placebo group

TC decrease by $26 \%$; TG decrease by $30 \%$; nonfatal Miocardial Iinfarction decrease by $50 \%$

160 patients with CAD and low HDL-C distributed in 4 arms and treated with: Group A: simvastatin 10-20 mg/d plus niacin 2-4 g/d; Group B: antioxidant; HATS Group C: simvastatin + niacin + antioxidant; Group D: placebo
LDL-C decrease by $42 \%$; HDL-C increase by $26 \%$; regression of severe coronary stenosis by $0.4 \%$ vs. placebo; $88 \%$ decrease of $\mathrm{CV}$ events (coronary death, MI or stroke, or revascularization) 


\section{CETP Inhibitors}

CETP inhibitors have been proposed over the years to raise HDL-C plasma levels, although clinical trials have failed to prove their hypothesized positive effects $[155,156]$. Among these, torcetrapib was the first CETP inhibitor developed to treat hypercholesterolemia and prevent atherosclerotic cardiovascular diseases. Although torcetrapib was effective in raising HDL-C and ApoA-I and reducing LDL-C with and without an added statin [156], phase 3 trials failed to demonstrate effects on atherosclerosis burden and cardiovascular deaths (RADIANCE and ILLUMINATE trials) [157,158]. Moreover, because of an excess of overall mortality and cardiovascular events, the development of torcetrapib was halted [156]. The excess deaths and adverse cardiovascular events in patients taking torcetrapib have been attributed to off-target effects independent from CETP inhibition [156,159]. Other potent and selective inhibitors of CETP have been developed and tested in clinical trials (such as dalcetrapib, anacetrapib, and evacetrapib). Although these drugs were effective in increasing HDL-C and reducing LDL-C without torcetrapib-like off-target liabilities, they failed to impact cardiovascular risk and outcomes [160-162]. Moreover, meta-analysis based on clinical trials carried out with niacin, statins, fibrates and CETP inhibitors have exhibited no decreases in CV mortality [160,163].

\section{Future Directions}

Clinical trials are investigating the role of new targets to evaluate cardioprotection by increasing specific HDL-C subclasses or improving HDL functions [164]. Reconstituted HDL (rHDL) therapies, including an HDL mimetic molecule (CER-001), an apoAI derivative (CSL112), and a recombinant human LCAT (ACP-501) together with the antibodies anti-apoAI (anti-ApoAI IgG) could represent the basis for the development of targets focused on HDL3 sub-class (functionally superior to HDL2) increases, or based on the HDL functions, improvements rather than necessarily increasing HDL-C which has already been tested without any encouraging results [161,162].

\section{Conclusions}

In summary, primary HALP is a heterogenous genetic lipid disorder and some pathogenic mechanisms are still not completely understood. The supposed protective role of HDL on CV risk have been extensively evaluated over the years, and several studies have shown that different mechanisms based on HDL-C increases by enhancing both the cholesterol efflux and the cholesterol esterification are not definitely anti-atherogenic. Moreover, the different metabolic scenarios and specific biochemical pathways governed by the numerous HDL-related genes need further studies in order to clarify in which way a similar HDL-C increase may induce atherogenic or athero-protective effects. New functional assays would be necessary to measure the HDL quality in a validated, reproducible and cost-effective manner to better understand the mechanisms related to cardiovascular protection.

Author Contributions: Writing—original draft preparation, A.B.C., A.G., and C.M.B.; Writingreview and editing, D.N., M.C., R.C., and E.N.; Supervision, A.B.C. and M.R.A. All authors have read and agreed to the published version of the manuscript.

Funding: This research received no external funding.

Data Availability Statement: Data sharing not applicable. No new data were created or analyzed in this study. Data sharing is not applicable to this article.

Conflicts of Interest: The authors declare no conflict of interest.

\section{References}

1. Zhou, H.; Gong, Y.; Wu, Q.; Ye, X.; Yu, B.; Lu, C.; Jiang, W.; Ye, J.; Fu, Z. Rare Diseases Related with Lipoprotein Metabolism. Adv. Exp. Med. Biol. 2020, 1276, 171-188. [CrossRef] [PubMed]

2. Yamashita, S.; Maruyama, T.; Hirano, K.-I.; Sakai, N.; Nakajima, N.; Matsuzawa, Y. Molecular mechanisms, lipoprotein abnormalities and atherogenicity of hyperalphalipoproteinemia. Atherosclerosis 2000, 152, 271-285. [CrossRef] 
3. Gordon, D.J.; Probstfield, J.L.; Garrison, R.J.; Neaton, J.D.; Castelli, W.P.; Knoke, J.D.; Jacobs, D.R.; Bangdiwala, S.; Tyroler, H.A. High-density lipoprotein cholesterol and cardiovascular disease. Four prospective American studies. Circulation 1989, 79, 8-15. [CrossRef]

4. Franceschini, G. Epidemiologic evidence for high-density lipoprotein cholesterol as a risk factor for coronary artery disease. Am. J. Cardiol. 2001, 88, 9-13. [CrossRef]

5. Voight, B.F.; Peloso, G.M.; Orho-Melander, M.; Frikke-Schmidt, R.; Barbalic, M.; Jensen, M.K.; Hindy, G.; Hólm, H.; Ding, E.L.; Johnson, T.; et al. Plasma HDL cholesterol and risk of myocardial infarction: A mendelian randomisation study. Lancet 2012, 380, 572-580. [CrossRef]

6. Haase, C.L.; Tybjærg-Hansen, A.; Qayyum, A.A.; Schou, J.; Nordestgaard, B.G.; Frikke-Schmidt, R. LCAT, HDL Cholesterol and Ischemic Cardiovascular Disease: A Mendelian Randomization Study of HDL Cholesterol in 54,500 Individuals. J. Clin. Endocrinol. Metab. 2012, 97, E248-E256. [CrossRef]

7. Zhong, S.; Sharp, D.S.; Grove, J.S.; Bruce, C.; Yano, K.; Curb, J.D.; Tall, A.R. Increased coronary heart disease in Japanese-American men with mutation in the cholesteryl ester transfer protein gene despite increased HDL levels. J. Clin. Investig. 1996, 97, 2917-2923. [CrossRef] [PubMed]

8. Curb, J.D.; Abbott, R.D.; Rodriguez, B.L.; Masaki, K.; Chen, R.; Sharp, D.S.; Tall, A.R. A prospective study of HDL-C and cholesteryl ester transfer protein gene mutations and the risk of coronary heart disease in the elderly. J. Lipid Res. 2004, 45, 948-953. [CrossRef] [PubMed]

9. Cuchel, M.; Rohatgi, A.; Sacks, F.M.; Guyton, J.R. JCL roundtable: High-density lipoprotein function and reverse cholesterol transport. J. Clin. Lipidol. 2018, 12, 1086-1094. [CrossRef]

10. Calabresi, L.; Gomaraschi, M.; Franceschini, G. Endothelial Protection by High-Density Lipoproteins. Arter. Thromb. Vasc. Biol. 2003, 23, 1724-1731. [CrossRef]

11. Libby, P. Inflammation in Atherosclerosis-No Longer a Theory. Clin. Chem. 2021, 67, 131-142. [CrossRef]

12. Kajani, S.; Curley, S.; McGillicuddy, F.C. Unravelling HDL-Looking beyond the Cholesterol Surface to the Quality Within. Int. J. Mol. Sci. 2018, 19, 1971. [CrossRef] [PubMed]

13. Brewer, H.; Fairwell, T.; LaRue, A.; Ronan, R.; Houser, A.; Bronzert, T. The amino acid sequence of human Apoa-I, an apolipoprotein isolated from high density lipoproteins. Biochem. Biophys. Res. Commun. 1978, 80, 623-630. [CrossRef]

14. Okada, T.; Ohama, T.; Takafuji, K.; Kanno, K.; Matsuda, H.; Sairyo, M.; Zhu, Y.; Saga, A.; Kobayashi, T.; Masuda, D.; et al. Shotgun proteomic analysis reveals proteome alterations in HDL of patients with cholesteryl ester transfer protein deficiency. J. Clin. Lipidol. 2019, 13, 317-325. [CrossRef]

15. Ouimet, M.; Barrett, T.J.; Fisher, E.A. HDL and Reverse Cholesterol Transport. Circ. Res. 2019, 124, 1505-1518. [CrossRef] [PubMed]

16. Rosales, C.; Gillard, B.K.; Xu, B.; Gotto, A.M.; Pownall, H.J. Revisiting Reverse Cholesterol Transport in the Context of HighDensity Lipoprotein Free Cholesterol Bioavailability. Methodist DeBakey Cardiovasc. J. 2019, 15, 47-54. [CrossRef]

17. Linton, M.F.; Tao, H.; Linton, E.F.; Yancey, P.G. SR-BI: A Multifunctional Receptor in Cholesterol Homeostasis and Atherosclerosis. Trends Endocrinol. Metab. 2017, 28, 461-472. [CrossRef]

18. Pownall, H.J.; Rosales, C.; Gillard, B.K.; Gotto, A.M. High-density lipoproteins, reverse cholesterol transport and atherogenesis. Nat. Rev. Cardiol. 2021, 1-12. [CrossRef]

19. Rohatgi, A.; Khera, A.; Berry, J.D.; Givens, E.G.; Ayers, C.R.; Wedin, K.E.; Neeland, I.J.; Yuhanna, I.S.; Rader, D.R.; De Lemos, J.A.; et al. HDL Cholesterol Efflux Capacity and Incident Cardiovascular Events. N. Engl. J. Med. 2014, 371, 2383-2393. [CrossRef]

20. Rosenson, R.S.; Brewer, H.B.; Davidson, W.S.; Fayad, Z.A.; Fuster, V.; Goldstein, J.; Hellerstein, M.; Jiang, X.-C.; Phillips, M.C.; Rader, D.J.; et al. Cholesterol Efflux and Atheroprotection. Circulation 2012, 125, 1905-1919. [CrossRef]

21. Beazer, J.D.; Patanapirunhakit, P.; Gill, J.M.; Graham, D.; Karlsson, H.; Ljunggren, S.; Mulder, M.T.; Freeman, D.J. High-density lipoprotein's vascular protective functions in metabolic and cardiovascular disease-Could extracellular vesicles be at play? Clin. Sci. 2020, 134, 2977-2986. [CrossRef] [PubMed]

22. Muñoz-Vega, M.; Massó, F.; Páez, A.; Vargas-Alarcón, G.; Coral-Vázquez, R.; Mas-Oliva, J.; Carreón-Torres, E.; Pérez-Méndez, Ó. HDL-Mediated Lipid Influx to Endothelial Cells Contributes to Regulating Intercellular Adhesion Molecule (ICAM)-1 Expression and eNOS Phosphorylation. Int. J. Mol. Sci. 2018, 19, 3394. [CrossRef] [PubMed]

23. Kudinov, V.A.; Alekseeva, O.Y.; Torkhovskaya, T.I.; Baskaev, K.K.; Artyushev, R.I.; Saburina, I.N.; Markin, S.S. High-Density Lipoproteins as Homeostatic Nanoparticles of Blood Plasma. Int. J. Mol. Sci. 2020, 21, 8737. [CrossRef] [PubMed]

24. Radulović, S.; Gottschalk, B.; Hörl, G.; Zardoya-Laguardia, P.; Schilcher, I.; Hallström, S.; Vujić, N.; Schmidt, K.; Trieb, M.; Graier, W.; et al. Endothelial lipase increases eNOS activating capacity of high-density lipoprotein. Biochim. Biophys. Acta BBA Mol. Cell Biol. Lipids 2020, 1865, 158612. [CrossRef]

25. Cervellati, C.; Vigna, G.B.; Trentini, A.; Sanz, J.M.; Zimetti, F.; Dalla Nora, E.; Morieri, M.L.; Zuliani, G.; Passaro, A. Paraoxonase-1 activities in individuals with different HDL circulating levels: Implication in reverse cholesterol transport and early vascular damage. Atherosclerosis 2019, 285, 64-70. [CrossRef]

26. Rosenson, R.S.; Brewer, H.B.; Ansell, B.; Barter, P.; Chapman, M.J.; Heinecke, J.W.; Kontush, A.; Tall, A.R.; Webb, N.R. Translation of High-Density Lipoprotein Function into Clinical Practice. Circulation 2013, 128, 1256-1267. [CrossRef]

27. Matsuzawa, Y.; Yamashita, S.; Kameda, K.; Kubo, M.; Tarui, S.; Hara, I. Marked hyper-HDL2-cholesterolemia associated with premature corneal opacity: A case report. Atherosclerosis 1984, 53, 207-212. [CrossRef] 
28. Deiana, L.; Pes, G.M.; Carru, C.; Campus, G.V.; Tidore, M.G.; Cherchi, G.M. Extremely high HDL levels in a patient with multiple symmetric lipomatosis. Clin. Chim. Acta 1993, 223, 143-147. [CrossRef]

29. Patsch, W.; Kuisk, I.; Glueck, C.; Schonfeld, G. Lipoproteins in familial hyperalphalipoproteinemia. Arter. Off. J. Am. Hear. Assoc. Inc. 1981, 1, 156-161. [CrossRef]

30. Ruiz-Ramie, J.J.; Barber, J.L.; Sarzynski, M.A. Effects of exercise on HDL functionality. Curr. Opin. Lipidol. 2019, 30, 16-23. [CrossRef] [PubMed]

31. Nova, E.; Mauro-Martín, I.S.; Díaz-Prieto, L.E.; Marcos, A. Wine and beer within a moderate alcohol intake is associated with higher levels of HDL-c and adiponectin. Nutr. Res. 2019, 63, 42-50. [CrossRef]

32. Hannuksela, M.; Marcel, Y.L.; Kesäniemi, Y.A.; Savolainen, M.J. Reduction in the concentration and activity of plasma cholesteryl ester transfer protein by alcohol. J. Lipid Res. 1992, 33, 737-744. [CrossRef]

33. Ramasamy, I. Update on the molecular biology of dyslipidemias. Clin. Chim. Acta 2016, 454, 143-185. [CrossRef]

34. Godsland, I.F. Biology: Risk factor modification by OCs and HRT lipids and lipoproteins. Maturitas 2004, 47, 299-303. [CrossRef]

35. Titov, V.N.; Tvorogova, M.G.; Kantardzhian, I.G.; Alamdarova, I.A.; Negovskaia, A.V. High density lipoprotein cholesterol in sec-ondary hyperlipoproteinemias. Lab Delo. 1983, 12, 11-17.

36. Guevara, M.; $\mathrm{Ng}$, B. Positive effect of hydroxychloroquine on lipid profiles of patients with rheumatoid arthritis: A Veterans Affair cohort. Eur. J. Rheumatol. 2021, 8, 62-66. [CrossRef]

37. Hargrove, G.M.; Junco, A.; Wong, N.C. Hormonal regulation of apolipoprotein AI. J. Mol. Endocrinol. 1999, 22, 103-111. [CrossRef]

38. Fragoulis, G.E.; Soulaidopoulos, S.; Sfikakis, P.P.; Dimitroulas, T.; Kitas, G.D. Effect of Biologics on Cardiovascular Inflammation: Mechanistic Insights and Risk Reduction. J. Inflamm. Res. 2021, 14, 1915-1931. [CrossRef] [PubMed]

39. Raygor, V.; Khera, A. New Recommendations and Revised Concepts in Recent Guidelines on the Management of Dyslipidemias to Prevent Cardiovascular Disease: The 2018 ACC/AHA and 2019 ESC/EAS Guidelines. Curr. Cardiol. Rep. 2020, 22, 1-6. [CrossRef] [PubMed]

40. Agellon, L.B.; Quinet, E.M.; Gillette, T.G.; Drayna, D.T.; Brown, M.L.; Tall, A.R. Organization of the human cholesteryl ester transfer protein gene. Biochemistry 1990, 29, 1372-1376. [CrossRef] [PubMed]

41. Oliveira, H.C.F.; Raposo, H.F. Cholesteryl Ester Transfer Protein and Lipid Metabolism and Cardiovascular Diseases. Adv. Exp. Med. Biol. 2020, 1276, 15-25. [CrossRef]

42. Ohnishi, T.; Tan, C.; Yokoyama, S. Selective Transfer of Cholesteryl Ester over Triglyceride by Human Plasma Lipid Transfer Protein between Apolipoprotein-Activated Lipid Microemulsions. Biochemistry 1994, 33, 4533-4542. [CrossRef]

43. Tall, A. Plasma Lipid Transfer Proteins. Annu. Rev. Biochem. 1995, 64, 235-257. [CrossRef] [PubMed]

44. Koizumi, J.; Mabuchi, H.; Yoshimura, A.; Michishita, I.; Takeda, M.; Itoh, H.; Sakai, Y.; Sakai, T.; Ueda, K.; Takeda, R. Deficiency of serum cholesteryl-ester transfer activity in patients with familial hyperalphalipoproteinaemia. Atherosclerosis 1985, 58, 175-186. [CrossRef]

45. Yamashita, S.; Matsuzawa, Y.; Okazaki, M.; Kako, H.; Yasugi, T.; Akioka, H.; Hirano, K.; Tarui, S. Small polydisperse low density lipoproteins in familial hyperalphalipoproteinemia with complete deficiency of cholesteryl ester transfer activity. Atherosclerosis 1988, 70, 7-12. [CrossRef]

46. Yokoyama, S.; Ueshima, H.; Miida, T.; Nakamura, M.; Takata, K.; Fukukawa, T.; Goto, T.; Harada-Shiba, M.; Sano, M.; Kato, K.; et al. High-Density Lipoprotein Levels Have Markedly Increased Over the Past Twenty Years in Japan. J. Atheroscler. Thromb. 2014, 21, 151-160. [CrossRef] [PubMed]

47. Nagano, M.; Yamashita, S.; Hirano, K.-I.; Takano, M.; Maruyama, T.; Ishihara, M.; Sagehashi, Y.; Kujiraoka, T.; Tanaka, K.; Hattori, H.; et al. Molecular mechanisms of cholesteryl ester transfer protein deficiency in Japanese. J. Atheroscler. Thromb. 2004, 11, 110-121. [CrossRef] [PubMed]

48. Maruyama, T.; Sakai, N.; Ishigami, M.; Hirano, K.-I.; Arai, T.; Okada, S.; Okuda, E.; Ohya, A.; Nakajima, N.; Kadowaki, K.; et al. Prevalence and phenotypic spectrum of cholesteryl ester transfer protein gene mutations in Japanese hyperalphalipoproteinemia. Atherosclerosis 2003, 166, 177-185. [CrossRef]

49. Inazu, A.; Jiang, X.C.; Haraki, T.; Yagi, K.; Kamon, N.; Koizumi, J.; Mabuchi, H.; Takeda, R.; Takata, K.; Moriyama, Y. Genetic cholesteryl ester transfer protein deficiency caused by two prevalent mutations as a major determinant of increased levels of high density lipoprotein cholesterol. J. Clin. Investig. 1994, 94, 1872-1882. [CrossRef]

50. Nagano, M.; Yamashita, S.; Hirano, K.-I.; Ito, M.; Maruyama, T.; Ishihara, M.; Sagehashi, Y.; Oka, T.; Kujiraoka, T.; Hattori, H.; et al. Two novel missense mutations in the CETP gene in Japanese hyperalphalipoproteinemic subjects: High-throughput assay by Invader®assay. J. Lipid Res. 2002, 43, 1011-1018. [CrossRef]

51. Gotoda, T.; Kinoshita, M.; Shimano, H.; Harada, K.; Shimada, M.; Ohsuga, J.; Teramoto, T.; Yazaki, Y.; Yamada, N. Cholesteryl Ester Transfer Protein Deficiency Caused by a Nonsense Mutation Detected in the Patient's Macrophage mRNA. Biochem. Biophys. Res. Commun. 1993, 194, 519-524. [CrossRef]

52. Thompson, J.F.; Reynolds, J.M.; Williams, S.P.; Wood, L.S.; Paciga, S.A.; Lloyd, D.B. Frequency and function of CETP variants among individuals of Asian ancestry. Atherosclerosis 2009, 202, 241-247. [CrossRef] [PubMed]

53. Teh, E.M.; Dolphin, P.J.; Breckenridge, W.C.; Tan, M.-H. Human plasma CETP deficiency: Identification of a novel mutation in exon 9 of the CETP gene in a Caucasian subject from North America. J. Lipid Res. 1998, 39, 442-456. [CrossRef] 
54. Rhyne, J.; Ryan, M.J.; White, C.; Chimonas, T.; Miller, M. The two novel CETP mutations Gln87X and Gln165X in a compound heterozygous state are associated with marked hyperalphalipoproteinemia and absence of significant coronary artery disease. J. Mol. Med. 2006, 84, 647-650. [CrossRef] [PubMed]

55. Van der Steeg, W.A.; Hovingh, G.K.; Klerkx, A.H.E.M.; Hutten, B.A.; Nootenboom, I.C.; Levels, J.H.M.; van Tol, A.; Dallinga-Thie, G.M.; Zwinderman, A.H.; Kastelein, J.J.P.; et al. Cholesteryl ester transfer protein and hyperalphalipoproteinemia in Caucasians. J. Lipid Res. 2007, 48, 674-682. [CrossRef]

56. Cefalu', A.B.; Noto, D.; Magnolo, L.; Pinotti, E.; Gomaraschi, M.; Martini, S.; Vigna, G.B.; Calabresi, L.; Tarugi, P.; Averna, M.R. Novel mutations of CETP gene in Italian subjects with hyeralphalipoproteinemia. Atherosclerosis 2009, 204, 202-207. [CrossRef]

57. Calabresi, L.; Nilsson, P.; Pinotti, E.; Gomaraschi, M.; Favari, E.; Adorni, M.P.; Bernini, F.; Sirtori, C.R.; Calandra, S.; Franceschini, G.; et al. A novel homozygous mutation in CETP gene as a cause of CETP deficiency in a caucasian kindred. Atherosclerosis 2009, 205, 506-511. [CrossRef] [PubMed]

58. Pirim, D.; Wang, X.; Niemsiri, V.; Radwan, Z.H.; Bunker, C.H.; Hokanson, J.E.; Hamman, R.F.; Barmada, M.M.; Demirci, F.Y.; Kamboh, M.I. Resequencing of the CETP gene in American whites and African blacks: Association of rare and common variants with HDL-cholesterol levels. Metabolism 2016, 65, 36-47. [CrossRef]

59. Okada, T.; Ohama, T.; Okazaki, M.; Kanno, K.; Matsuda, H.; Sairyo, M.; Zhu, Y.; Saga, A.; Kobayashi, T.; Masuda, D.; et al. Particle number analysis of lipoprotein subclasses by gel permeation HPLC in patients with cholesteryl ester transfer protein deficiency. PLoS ONE 2018, 13, e0190875. [CrossRef] [PubMed]

60. Sakai, N.; Matsuzawa, Y.; Hirano, K.; Yamashita, S.; Nozaki, S.; Ueyama, Y.; Kubo, M.; Tarui, S. Detection of two species of low density lipoprotein particles in cholesteryl ester transfer protein deficiency. Arter. Thromb. A J. Vasc. Biol. 1991, 11, 71-79. [CrossRef] [PubMed]

61. Arai, T.; Tsukada, T.; Murase, T.; Matsumoto, K. Particle size analysis of high density lipoproteins in patients with genetic cholesteryl ester transfer protein deficiency. Clin. Chim. Acta 2000, 301, 103-117. [CrossRef]

62. Ishigami, M.; Yamashita, S.; Sakai, N.; Aral, T.; Hirano, K.-I.; Hiraoka, H.; Kameda-Takemura, K.; Matsuzawa, Y. Large and Cholesteryl Ester-Rich High-Density Lipoproteins in Cholesteryl Ester Transfer Protein (CETP) Deficiency Can Not Protect Macrophages from Cholesterol Accumulation Induced by Acetylated Low-Density Lipoproteins. J. Biochem. 1994, 116, $257-262$. [CrossRef] [PubMed]

63. Ohta, T.; Nakamura, R.; Takata, R.; Saito, Y.; Yamashita, S.; Horiuchi, S.; Matsuda, I. Structural and functional differences of sub-species of apoA-I-containing lipoprotein in patients with plasma cholesteryl ester transfer protein deficiency. J. Lipid Res. 1995, 36, 696-704. [CrossRef]

64. Inazu, A.; Brown, M.L.; Hesler, C.B.; Agellon, L.B.; Koizumi, J.; Takata, K.; Maruhama, Y.; Mabuchi, H.; Tall, A.R. Increased High-Density Lipoprotein Levels Caused by a Common Cholesteryl-Ester Transfer Protein Gene Mutation. N. Engl. J. Med. 1990, 323, 1234-1238. [CrossRef] [PubMed]

65. Moriyama, Y.; Okamura, T.; Inazu, A.; Doi, M.; Iso, H.; Mouri, Y.; Ishikawa, Y.; Suzuki, H.; Iida, M.; Koizumi, J.; et al. A Low Prevalence of Coronary Heart Disease among Subjects with Increased High-Density Lipoprotein Cholesterol Levels, Including Those with Plasma Cholesteryl Ester Transfer Protein Deficiency. Prev. Med. 1998, 27, 659-667. [CrossRef]

66. Borggreve, S.E.; Hillege, H.L.; Wolffenbuttel, B.H.R.; De Jong, P.E.; Zuurman, M.W.; Van Der Steege, G.; Van Tol, A.; Dullaart, R.P.F. An Increased Coronary Risk Is Paradoxically Associated with Common Cholesteryl Ester Transfer Protein Gene Variations That Relate to Higher High-Density Lipoprotein Cholesterol: A Population-Based Study. J. Clin. Endocrinol. Metab. 2006, 91, 3382-3388. [CrossRef]

67. Kolovou, V.; Diakoumakou, O.; Papazafiropoulou, A.K.; Katsiki, N.; Fragopoulou, E.; Vasiliadis, I.; Degiannis, D.; Duntas, L.; Antonopoulou, S.; Kolovou, G. Biomarkers and Gene Polymorphisms in Members of Long- and Short-lived Families: A Longevity Study. Open Cardiovasc. Med. J. 2018, 12, 59-70. [CrossRef]

68. Pirim, D.; Bunker, C.H.; Hokanson, J.E.; Hamman, R.F.; Demirci, F.Y.; Kamboh, M.I. Hepatic lipase (LIPC) sequencing in individuals with extremely high and low high-density lipoprotein cholesterol levels. PLoS ONE 2020, 15, e0243919. [CrossRef]

69. Chatterjee, C.; Sparks, D.L. Hepatic Lipase, High Density Lipoproteins, and Hypertriglyceridemia. Am. J. Pathol. 2011, 178, 1429-1433. [CrossRef]

70. Tani, M.; Horvath, K.V.; Lamarche, B.; Couture, P.; Burnett, J.R.; Schaefer, E.J.; Asztalos, B.F. High-density lipoprotein subpopulation profiles in lipoprotein lipase and hepatic lipase deficiency. Atherosclerosis 2016, 253, 7-14. [CrossRef]

71. Rouhani, N.; Young, E.; Chatterjee, C.; Sparks, D.L. HDL Composition Regulates Displacement of Cell Surface-Bound Hepatic Lipase. Lipids 2008, 43, 793-804. [CrossRef]

72. Kobayashi, J. Which is the Best Predictor for the Development of Atherosclerosis Among Circulating Lipoprotein Lipase, Hepatic Lipase, and Endothelial Lipase? J. Atheroscler. Thromb. 2019, 26, 758-759. [CrossRef]

73. Carlson, L.A.; Holmquist, L.; Nilsson-Ehle, P. Deficiency of Hepatic Lipase Activity in Post-heparin Plasma in Familial Hyper- $\alpha-$ Triglyceridemia. Acta Med. Scand. 2009, 219, 435-447. [CrossRef] [PubMed]

74. Breckenridge, W.; Little, J.; Alaupovic, P.; Wang, C.; Kuksis, A.; Kakis, G.; Lindgren, F.; Gardiner, G. Lipoprotein abnormalities associated with a familial deficiency of hepatic lipase. Atherosclerosis 1982, 45, 161-179. [CrossRef]

75. Zambon, A.; Deeb, S.S.; Pauletto, P.; Crepaldi, G.; Brunzell, J.D. Hepatic lipase: A marker for cardiovascular disease risk and response to therapy. Curr. Opin. Lipidol. 2003, 14, 179-189. [CrossRef] 
76. McCaskie, P.; Cadby, G.; Hung, J.; McQuillan, B.; Chapman, C.; Carter, K.; Thompson, P.; Palmer, L.; Beilby, J.; McQuillan, B.; et al. The C-480T hepatic lipase polymorphism is associated with HDL-C but not with risk of coronary heart disease. Clin. Genet. 2006, 70, 114-121. [CrossRef] [PubMed]

77. Williams, P.T. Quantile-Dependent Expressivity and Gene-Lifestyle Interactions Involving High-Density Lipoprotein Cholesterol. Lifestyle Genom. 2021, 14, 1-19. [CrossRef] [PubMed]

78. Hegele, R.A.; Little, J.; Connelly, P.W. Compound heterozygosity for mutant hepatic lipase in familial hepatic lipase deficiency. Biochem. Biophys. Res. Commun. 1991, 179, 78-84. [CrossRef]

79. Knudsen, P.; Antikainen, M.; Ehnholm, S.; Uusi-Oukari, M.; Tenkanen, H.; Lahdenpera, S.; Kahri, J.; Tilly-Kiesi, M.; Bensadoun, A.; Taskinen, M.R.; et al. A compound heterozygote for hepatic lipase gene mutations Leu334>Phe and Thr383>Met: Cor-relation between hepatic lipase activity and phenotypic expression. J. Lipid Res. 1996, 37, 825-834. [CrossRef]

80. Brand, K.; Dugi, K.A.; Brunzell, J.D.; Nevin, D.N.; Santamarina-Fojo, S. A novel A->G mutation in intron I of the hepatic lipase gene leads to alternative splicing resulting in enzyme deficiency. J. Lipid Res. 1996, 37, 213-223. [CrossRef]

81. Hegele, R.; Lupien, P.; Gagne, C.; Brun, L.; Little, J.; Connelly, P.; Vezina, C.; Moorjani, S. A Hepatic Lipase Gene Mutation Associated with Heritable Lipolytic Deficiency. J. Clin. Endocrinol. Metab. 1991, 72, 730-732. [CrossRef]

82. Ruel, I.L.; Couture, P.; Gagné, C.; Deshaies, Y.; Simard, J.; Hegele, R.A.; Lamarche, B. Characterization of a novel mutation causing hepatic lipase deficiency among French Canadians. J. Lipid Res. 2003, 44, 1508-1514. [CrossRef]

83. Gangabadage, C.S.; Zdunek, J.; Tessari, M.; Nilsson, S.; Olivecrona, G.; Wijmenga, S.S. Structure and Dynamics of Human Apolipoprotein CIII. J. Biol. Chem. 2008, 283, 17416-17427. [CrossRef]

84. Pollin, T.I.; Damcott, C.M.; Shen, H.; Ott, S.H.; Shelton, J.; Horenstein, R.B.; Post, W.; McLenithan, J.C.; Bielak, L.F.; Peyser, P.A.; et al. A Null Mutation in Human APOC3 Confers a Favorable Plasma Lipid Profile and Apparent Cardioprotection. Science 2008, 322, 1702-1705. [CrossRef]

85. Crosby, J.H.; Peloso, G.M.; Auer, P.L.; Crosslin, D.R.; Stitziel, N.; Lange, L.A.; Lu, Y.; Tang, Z.Z.; Zhang, H.; Hindy, G.; et al. Loss-of-Function Mutations in APOC3, Triglycerides, and Coronary Disease. N. Engl. J. Med. 2014, 371, 22-31. [CrossRef]

86. Bochem, A.; Van Capelleveen, J.; Dallinga-Thie, G.; Schimmel, A.; Motazacker, M.; Tietjen, I.; Singaraja, R.; Hayden, M.; Kastelein, J.; Stroes, E.; et al. Two novel mutations in apolipoprotein C3 underlie atheroprotective lipid profiles in families. Clin. Genet. 2013, 85, 433-440. [CrossRef]

87. Von Eckardstein, A.; Holz, H.; Sandkamp, M.; Weng, W.; Funke, H.; Assmann, G. Apolipoprotein C-III(Lys58--Glu). Identification of an apolipoprotein C-III variant in a family with hyperalphalipoproteinemia. J. Clin. Investig. 1991, 87, $1724-1731$. [CrossRef] [PubMed]

88. Yu, L.; Dai, Y.; Mineo, C. Novel Functions of Endothelial Scavenger Receptor Class B Type I. Curr. Atheroscler. Rep. 2021, 23, 1-9. [CrossRef] [PubMed]

89. Shen, W.-J.; Azhar, S.; Kraemer, F.B. SR-B1: A Unique Multifunctional Receptor for Cholesterol Influx and Efflux. Annu. Rev. Physiol. 2018, 80, 95-116. [CrossRef] [PubMed]

90. Hildebrand, R.B.; Lammers, B.; Meurs, I.; Korporaal, S.J.; De Haan, W.; Zhao, Y.; Kruijt, J.K.; Praticò, D.; Schimmel, A.W.; Holleboom, A.G.; et al. Restoration of High-Density Lipoprotein Levels by Cholesteryl Ester Transfer Protein Expression in Scavenger Receptor Class B Type I (SR-BI) Knockout Mice Does Not Normalize Pathologies Associated with SR-BI Deficiency. Arter. Thromb. Vasc. Biol. 2010, 30, 1439-1445. [CrossRef]

91. Hoekstra, M.; Meurs, I.; Koenders, M.; Out, R.; Hildebrand, R.B.; Kruijt, J.K.; Van Eck, M.; Van Berkel, T.J.C. Absence of HDL cholesteryl ester uptake in mice via SR-BI impairs an adequate adrenal glucocorticoid-mediated stress response to fasting. J. Lipid Res. 2008, 49, 738-745. [CrossRef]

92. Chadwick, A.C.; Sahoo, D. Functional Characterization of Newly-Discovered Mutations in Human SR-BI. PLoS ONE 2012, 7, e45660. [CrossRef] [PubMed]

93. Brunham, L.R.; Tietjen, I.; Bochem, A.E.; Singaraja, R.R.; Franchini, P.L.; Radomski, C.; Mattice, M.; Legendre, A.; Hovingh, G.K.; Kastelein, J.J.P.; et al. Novel mutations in scavenger receptor BI associated with high HDL cholesterol in humans. Clin. Genet. 2011, 79, 575-581. [CrossRef]

94. Vergeer, M.; Korporaal, S.J.; Franssen, R.; Meurs, I.; Out, R.; Hovingh, G.K.; Hoekstra, M.; Sierts, J.A.; Dallinga-Thie, G.M.; Motazacker, M.M.; et al. Genetic Variant of the Scavenger Receptor BI in Humans. N. Engl. J. Med. 2011, 364, 136-145. [CrossRef]

95. Helgadottir, A.; Sulem, P.; Thorgeirsson, G.; Gretarsdottir, S.; Thorleifsson, G.; Jensson, B.Ö.; Arnadottir, G.A.; Olafsson, I.; Eyjolfsson, G.I.; Sigurdardottir, O.; et al. Rare SCARB1 mutations associate with high-density lipoprotein cholesterol but not with coronary artery disease. Eur. Heart J. 2018, 39, 2172-2178. [CrossRef]

96. Davidson, J.; Rotondo, D. Scavenger receptor B1 mutation, elevated HDL cholesterol and a paradoxical increase in atherosclerosis. Curr. Opin. Lipidol. 2016, 27, 541-542. [CrossRef] [PubMed]

97. Zanoni, P.; Khetarpal, S.A.; Larach, D.B.; Hancock-Cerutti, W.F.; Millar, J.S.; Cuchel, M.; DerOhannessian, S.; Kontush, A.; Surendran, P.; Saleheen, D.; et al. Rare variant in scavenger receptor BI raises HDL cholesterol and increases risk of coronary heart disease. Science 2016, 351, 1166-1171. [CrossRef] [PubMed]

98. Yang, X.; Sethi, A.; Yanek, L.R.; Knapper, C.; Nordestgaard, B.G.; Tybjærg-Hansen, A.; Becker, D.M.; Mathias, R.A.; Remaley, A.T.; Becker, L.C. SCARB1Gene Variants Are Associated with the Phenotype of Combined High High-Density Lipoprotein Cholesterol and High Lipoprotein (a). Circ. Cardiovasc. Genet. 2016, 9, 408-418. [CrossRef] 
99. Schilcher, I.; Ledinski, G.; Radulović, S.; Hallström, S.; Eichmann, T.; Madl, T.; Zhang, F.; Leitinger, G.; Kolb-Lenz, D.; Darnhofer, B.; et al. Endothelial lipase increases antioxidative capacity of high-density lipoprotein. Biochim. Biophys. Acta BBA Mol. Cell Biol. Lipids 2019, 1864, 1363-1374. [CrossRef]

100. Jahangiri, A.; Rader, D.J.; Marchadier, D.; Curtiss, L.K.; Bonnet, D.J.; Rye, K.-A. Evidence that endothelial lipase remodels high density lipoproteins without mediating the dissociation of apolipoprotein A-I. J. Lipid Res. 2005, 46, 896-903. [CrossRef]

101. Schilcher, I.; Kern, S.; Hrzenjak, A.; Eichmann, T.O.; Stojakovic, T.; Scharnagl, H.; Duta-Mare, M.; Kratky, D.; Marsche, G.; Frank, S. Impact of Endothelial Lipase on Cholesterol Efflux Capacity of Serum and High-density Lipoprotein. Sci. Rep. 2017, 7, 12485. [CrossRef]

102. Escolà-Gil, J.C.; Chen, X.; Julve, J.; Quesada, H.; Santos, D.; Metso, J.; Tous, M.; Jauhiainen, M.; Blanco-Vaca, F. Hepatic lipase- and endothelial lipase-deficiency in mice promotes macrophage-to-feces RCT and HDL antioxidant properties. Biochim. et Biophys. Acta BBA Mol. Cell Biol. Lipids 2013, 1831, 691-697. [CrossRef]

103. Edmondson, A.C.; Brown, R.J.; Kathiresan, S.; Cupples, L.A.; Demissie, S.; Manning, A.K.; Jensen, M.K.; Rimm, E.B.; Wang, J.; Rodrigues, A.; et al. Loss-of-function variants in endothelial lipase are a cause of elevated HDL cholesterol in humans. J. Clin. Investig. 2009, 119, 1042-1050. [CrossRef] [PubMed]

104. Khetarpal, S.A.; Edmondson, A.C.; Raghavan, A.; Neeli, H.; Jin, W.; Badellino, K.O.; Demissie, S.; Manning, A.K.; DerOhannessian, S.L.; Wolfe, M.L.; et al. Mining the LIPG Allelic Spectrum Reveals the Contribution of Rare and Common Regulatory Variants to HDL Cholesterol. PLoS Genet. 2011, 7, e1002393. [CrossRef]

105. Singaraja, R.R.; Sivapalaratnam, S.; Hovingh, K.; Dubé, M.-P.; Castro-Perez, J.; Collins, H.L.; Adelman, S.J.; Riwanto, M.; Manz, J.; Hubbard, B.; et al. The Impact of Partial and Complete Loss-of-Function Mutations in Endothelial Lipase on High-Density Lipoprotein Levels and Functionality in Humans. Circ. Cardiovasc. Genet. 2013, 6, 54-62. [CrossRef]

106. Boekholdt, S.M.; Thompson, J.F. Natural genetic variation as a tool in understanding the role of CETP in lipid levels and disease. J. Lipid Res. 2003, 44, 1080-1093. [CrossRef]

107. Wu, Z.; Lou, Y.; Qiu, X.; Liu, Y.; Lu, L.; Chen, Q.; Jin, W. Association of cholesteryl ester transfer protein (CETP) gene polymorphism, high density lipoprotein cholesterol and risk of coronary artery disease: A meta-analysis using a Mendelian randomization approach. BMC Med. Genet. 2014, 15, 1-17. [CrossRef]

108. Thompson, A.; Di Angelantonio, E.; Sarwar, N.; Erqou, S.; Saleheen, D.; Dullaart, R.P.F.; Keavney, B.; Ye, Z.; Danesh, J. Association of Cholesteryl Ester Transfer Protein Genotypes with CETP Mass and Activity, Lipid Levels, and Coronary Risk. JAMA 2008, 299, 2777-2788. [CrossRef] [PubMed]

109. Klerkx, A.H.; Tanck, M.W.; Kastelein, J.J.; Molhuizen, H.O.; Jukema, J.W.; Zwinderman, A.H.; Kuivenhoven, J.A. Haplotype analysis of the CETP gene: Not TaqIB, but the closely linked $-629 \mathrm{C}->\mathrm{A}$ polymorphism and a novel promoter variant are independently associated with CETP concentration. Hum. Mol. Genet. 2003, 12, 111-123. [CrossRef] [PubMed]

110. Ordovas, J.M.; Cupples, L.A.; Corella, D.; Otvos, J.D.; Osgood, D.; Martinez, A.; Lahoz, C.; Coltell, O.; Wilson, P.W.F.; Schaefer, E.J. Association of Cholesteryl Ester Transfer Protein-TaqIB Polymorphism with Variations in Lipoprotein Subclasses and Coronary Heart Disease Risk. Arter. Thromb. Vasc. Biol. 2000, 20, 1323-1329. [CrossRef]

111. Brousseau, M.E.; O'Connor, J.J.; Ordovas, J.M.; Collins, D.; Otvos, J.D.; Massov, T.; McNamara, J.R.; Rubins, H.B.; Robins, S.J.; Schaefer, E.J. Cholesteryl Ester Transfer ProteinTaqI B2B2 Genotype Is Associated with Higher HDL Cholesterol Levels and Lower Risk of Coronary Heart Disease End Points in Men With HDL Deficiency. Arter. Thromb. Vasc. Biol. 2002, 22, 1148-1154. [CrossRef] [PubMed]

112. Freeman, D.J.; Samani, N.J.; Wilson, V.; McMahon, A.D.; Braund, P.S.; Cheng, S.; Caslake, M.J.; Packard, C.J.; Gaffney, D. A polymorphism of the cholesteryl ester transfer protein gene predicts cardiovascular events in non-smokers in the West of Scotland Coronary Prevention Study. Eur. Hear. J. 2003, 24, 1833-1842. [CrossRef]

113. Blankenberg, S.; Rupprecht, H.J.; Bickel, C.; Jiang, X.-C.; Poirier, O.; Lackner, K.J.; Meyer, J.; Cambien, F.; Tiret, L. Common genetic variation of the cholesteryl ester transfer protein gene strongly predicts future cardiovascular death in patients with coronary artery disease. J. Am. Coll. Cardiol. 2003, 41, 1983-1989. [CrossRef]

114. Lu, H.; Inazu, A.; Moriyama, Y.; Higashikata, T.; Kawashiri, M.-A.; Yu, W.; Huang, Z.; Okamura, T.; Mabuchi, H. Haplotype analyses of cholesteryl ester transfer protein gene promoter: A clue to an unsolved mystery of TaqIB polymorphism. J. Mol. Med. 2003, 81, 246-255. [CrossRef]

115. Zhang, Y.-X.; Yang, Z.-X.; Zhou, D.-F.; Su, Y.; Tang, L.; Qiu, Y.-M.; Cai, W.-W. CETP polymorphisms confer genetic contribution to centenarians of Hainan, south of China. Asian Pac. J. Trop. Med. 2016, 9, 872-876. [CrossRef]

116. Motazacker, M.M.; Peter, J.; Treskes, M.; Shoulders, C.C.; Kuivenhoven, J.A.; Hovingh, G.K. Evidence of a Polygenic Origin of Extreme High-Density Lipoprotein Cholesterol Levels. Arter. Thromb. Vasc. Biol. 2013, 33, 1521-1528. [CrossRef]

117. Boes, E.; Coassin, S.; Kollerits, B.; Heid, I.M.; Kronenberg, F. Genetic-epidemiological evidence on genes associated with HDL cholesterol levels: A systematic in-depth review. Exp. Gerontol. 2009, 44, 136-160. [CrossRef] [PubMed]

118. Weissglas-Volkov, D.; Pajukanta, P. Genetic causes of high and low serum HDL-cholesterol. J. Lipid Res. 2010, 51, 2032-2057. [CrossRef]

119. Kuwano, T.; Bi, X.; Cipollari, E.; Yasuda, T.; Lagor, W.R.; Szapary, H.J.; Tohyama, J.; Millar, J.S.; Billheimer, J.T.; Lyssenko, N.N.; et al. Overexpression and deletion of phospholipid transfer protein reduce HDL mass and cholesterol efflux capacity but not macrophage reverse cholesterol transport. J. Lipid Res. 2017, 58, 731-741. [CrossRef] [PubMed] 
120. Oates, C.P.; Koenig, D.; Rhyne, J.; Bogush, N.; O'Connell, J.; Mitchell, B.D.; Miller, M. Novel polymorphisms associated with hyperalphalipoproteinemia and apparent cardioprotection. J. Clin. Lipidol. 2018, 12, 110-115. [CrossRef]

121. Huggins, G.S.; Papandonatos, G.; Erar, B.; Belalcazar, L.M.; Brautbar, A.; Ballantyne, C.; Kitabchi, A.E.; Wagenknecht, L.E.; Knowler, W.C.; Pownall, H.; et al. Do Genetic Modifiers of High-Density Lipoprotein Cholesterol and Triglyceride Levels also Modify Their Response to a Lifestyle Intervention in the Setting of Obesity and Type-2 Diabetes Mellitus? Circ. Cardiovasc. Genet. 2013, 6, 391-399. [CrossRef]

122. Kathiresan, S.; Willer, C.J.; Peloso, G.M.; Demissie, S.; Musunuru, K.; Schadt, E.E.; Kaplan, L.; Bennett, D.; Li, Y.; Tanaka, T.; et al. Common variants at 30 loci contribute to polygenic dyslipidemia. Nat. Genet. 2008, 41, 56-65. [CrossRef]

123. Gofman, J.W.; Young, W.; Tandy, R. Ischemic Heart Disease, Atherosclerosis, and Longevity. Circulation 1966, 34, 679-697. [CrossRef]

124. Gordon, T.; Castelli, W.P.; Hjortland, M.C.; Kannel, W.B.; Dawber, T.R. High density lipoprotein as a protective factor against coronary heart disease: The Framingham Study. Am. J. Med. 1977, 62, 707-714. [CrossRef]

125. Rye, K.-A.; Barter, P.J. Cardioprotective functions of HDLs. J. Lipid Res. 2014, 55, 168-179. [CrossRef]

126. Feghaly, J.; Mooradian, A.D. The Rise and Fall "ing" of the HDL Hypothesis. Drugs 2020, 80, 353-362. [CrossRef] [PubMed]

127. Hamer, M.; O'Donovan, G.; Stamatakis, E. High-Density Lipoprotein Cholesterol and Mortality. Arter. Thromb. Vasc. Biol. 2018, 38, 669-672. [CrossRef] [PubMed]

128. Rahilly-Tierney, C.R.; Spiro, A.; Vokonas, P.; Gaziano, J.M. Relation Between High-Density Lipoprotein Cholesterol and Survival to Age 85 Years in Men (from the VA Normative Aging Study). Am. J. Cardiol. 2011, 107, 1173-1177. [CrossRef]

129. Feitosa, M.F.; Lunetta, K.L.; Wang, L.; Wojczynski, M.K.; Kammerer, C.M.; Perls, T.; Schupf, N.; Christensen, K.; Murabito, J.M.; Province, M.A. Gene discovery for high-density lipoprotein cholesterol level change over time in prospective family studies. Atherosclerosis 2020, 297, 102-110. [CrossRef] [PubMed]

130. Barter, P.; Genest, J. HDL cholesterol and ASCVD risk stratification: A debate. Atherosclerosis 2019, 283, 7-12. [CrossRef]

131. Boekholdt, S.M.; Arsenault, B.J.; Hovingh, G.K.; Mora, S.; Pedersen, T.R.; LaRosa, J.C.; Welch, K.; Amarenco, P.; DeMicco, D.A.; Tonkin, A.M.; et al. Levels and Changes of HDL Cholesterol and Apolipoprotein A-I in Relation to Risk of Cardiovascular Events Among Statin-Treated Patients. Circulation 2013, 128, 1504-1512. [CrossRef] [PubMed]

132. Khera, A.V.; Demler, O.; Adelman, S.J.; Collins, H.L.; Glynn, R.J.; Ridker, P.M.; Rader, D.J.; Mora, S. Cholesterol Efflux Capacity, High-Density Lipoprotein Particle Number, and Incident Cardiovascular Events. Circulation 2017, 135, 2494-2504. [CrossRef] [PubMed]

133. Cuchel, M.; Rader, D.J. Macrophage Reverse Cholesterol Transport. Circulation 2006, 113, 2548-2555. [CrossRef]

134. Madsen, C.M.; Varbo, A.; Nordestgaard, B.G. Extreme high high-density lipoprotein cholesterol is paradoxically associated with high mortality in men and women: Two prospective cohort studies. Eur. Hear. J. 2017, 38, 2478-2486. [CrossRef] [PubMed]

135. Madsen, C.M.; Nordestgaard, B.G. Is It Time for New Thinking About High-Density Lipoprotein? Arter. Thromb. Vasc. Biol. 2018, 38, 484-486. [CrossRef]

136. Agerholm-Larsen, B.; Tybjærg-Hansen, A.; Schnohr, P.; Steffensen, R.; Nordestgaard, B.G. Common Cholesteryl Ester Transfer Protein Mutations, Decreased HDL Cholesterol, and Possible Decreased Risk of Ischemic Heart Disease. Circulation 2000, 102, 2197-2203. [CrossRef]

137. Ko, D.T.; Alter, D.A.; Guo, H.; Koh, M.; Lau, G.; Austin, P.C.; Booth, G.L.; Hogg, W.; Jackevicius, C.A.; Lee, D.; et al. High-Density Lipoprotein Cholesterol and Cause-Specific Mortality in Individuals without Previous Cardiovascular Conditions. J. Am. Coll. Cardiol. 2016, 68, 2073-2083. [CrossRef]

138. Bowe, B.; Xie, Y.; Xian, H.; Balasubramanian, S.; Zayed, M.A.; Al-Aly, Z. High Density Lipoprotein Cholesterol and the Risk of All-Cause Mortality among U.S. Veterans. Clin. J. Am. Soc. Nephrol. 2016, 11, 1784-1793. [CrossRef]

139. Siddiqi, H.K.; Kiss, D.; Rader, D. HDL-cholesterol and cardiovascular disease. Curr. Opin. Cardiol. 2015, 30, 536-542. [CrossRef] [PubMed]

140. Garg, A.; Sharma, A.; Krishnamoorthy, P.; Garg, J.; Virmani, D.; Sharma, T.; Stefanini, G.; Kostis, J.B.; Mukherjee, D.; Sikorskaya, E. Role of Niacin in Current Clinical Practice: A Systematic Review. Am. J. Med. 2017, 130, 173-187. [CrossRef] [PubMed]

141. Schandelmaier, S.; Briel, M.; Saccilotto, R.; Olu, K.K.; Arpagaus, A.; Hemkens, L.; Nordmann, A.J. Niacin for primary and secondary prevention of cardiovascular events. Cochrane Database Syst. Rev. 2017, 6, CD009744. [CrossRef] [PubMed]

142. Franceschini, G.; Favari, E.; Calabresi, L.; Simonelli, S.; Bondioli, A.; Adorni, M.P.; Zimetti, F.; Gomaraschi, M.; Coutant, K.; Rossomanno, S.; et al. Differential effects of fenofibrate and extended-release niacin on high-density lipoprotein particle size distribution and cholesterol efflux capacity in dyslipidemic patients. J. Clin. Lipidol. 2013, 7, 414-422. [CrossRef]

143. D'Andrea, E.; Hey, S.P.; Ramirez, C.L.; Kesselheim, A.S. Assessment of the Role of Niacin in Managing Cardiovascular Disease Outcomes: A Systematic Review and Meta-analysis. JAMA Netw. Open 2019, 2, e192224. [CrossRef] [PubMed]

144. The AIM-HIGH Investigators. Niacin in Patients with Low HDL Cholesterol Levels Receiving Intensive Statin Therapy. N. Engl. J. Med. 2011, 365, 2255-2267. [CrossRef]

145. The HPS2-THRIVE Collaborative Group. Effects of Extended-Release Niacin with Laropiprant in High-Risk Patients. N. Engl. J. Med. 2014, 371, 203-212. [CrossRef] [PubMed]

146. Adiels, M.; Chapman, M.J.; Robillard, P.; Krempf, M.; Laville, M.; Borén, J. Niacin action in the atherogenic mixed dyslipidemia of metabolic syndrome: Insights from metabolic biomarker profiling and network analysis. J. Clin. Lipidol. 2018, 12, 810-821. [CrossRef] 
147. Canner, P.L.; Berge, K.G.; Wenger, N.K.; Stamler, J.; Friedman, L.; Prineas, R.J.; Friedewald, W. Fifteen year mortality in Coronary Drug Project patients: Long-term benefit with niacin. J. Am. Coll. Cardiol. 1986, 8, 1245-1255. [CrossRef]

148. Taylor, A.J.; Sullenberger, L.E.; Lee, H.J.; Lee, J.K.; Grace, K.A. Arterial Biology for the Investigation of the Treatment Effects of Reducing Cholesterol (ARBITER) 2. Circulation 2004, 110, 3512-3517. [CrossRef]

149. Villines, T.C.; Stanek, E.J.; Devine, P.J.; Turco, M.; Miller, M.; Weissman, N.J.; Griffen, L.; Taylor, A.J. The ARBITER 6-HALTS Trial (Arterial Biology for the Investigation of the Treatment Effects of Reducing Cholesterol 6-HDL and LDL Treatment Strategies in Atherosclerosis): Final Results and the Impact of Medication Adherence, Dose, and Treatment Duration. J. Am. Coll. Cardiol. 2010, 55, 2721-2726. [CrossRef]

150. Whitney, E.J.; Krasuski, R.A.; Personius, B.E.; Michalek, J.E.; Maranian, A.M.; Kolasa, M.W.; Monick, E.; Brown, B.G.; Gotto, A.M. A Randomized Trial of a Strategy for Increasing High-Density Lipoprotein Cholesterol Levels: Effects on Progression of Coronary Heart Disease and Clinical Events. Ann. Intern. Med. 2005, 142, 95-104. [CrossRef]

151. Blankenhorn, D.H.; Nessim, S.A.; Johnson, R.L.; Sanmarco, M.E.; Azen, S.P.; Cashin-Hemphill, L. Beneficial effects of combined coles-tipol-niacin therapy on coronary atherosclerosis and coronary venous bypass grafts. JAMA 1987, 257, 3233-3240. [CrossRef] [PubMed]

152. Carlson, L.; Danielson, M.; Ekberg, I.; Klintemar, B.; Rosenhamer, G. Reduction of myocardial reinfarction by the combined treatment with clofibrate and nicotinic acid. Atherosclerosis 1977, 28, 81-86. [CrossRef]

153. Williams, P.T.; Zhao, X.-Q.; Marcovina, S.M.; Brown, B.G.; Krauss, R.M. Levels of Cholesterol in Small LDL Particles Predict Atherosclerosis Progression and Incident CHD in the HDL-Atherosclerosis Treatment Study (HATS). PLoS ONE 2013, 8, e56782. [CrossRef]

154. Nicholls, S.J.; Brandrup-Wognsen, G.; Palmer, M.; Barter, P.J. Meta-analysis of Comparative Efficacy of Increasing Dose of Atorvastatin Versus Rosuvastatin Versus Simvastatin on Lowering Levels of Atherogenic Lipids (from VOYAGER). Am. J. Cardiol. 2010, 105, 69-76. [CrossRef] [PubMed]

155. Estrada-Luna, D.; Ortiz-Rodriguez, M.A.; Medina-Briseño, L.; Carreón-Torres, E.; Izquierdo-Vega, J.A.; Sharma, A.; Cancino-Díaz, J.C.; Pérez-Méndez, O.; Belefant-Miller, H.; Betanzos-Cabrera, G. Current Therapies Focused on High-Density Lipoproteins Associated with Cardiovascular Disease. Molecules 2018, 23, 2730. [CrossRef]

156. Tall, A.R.; Rader, D.J. Trials and Tribulations of CETP Inhibitors. Circ. Res. 2018, 122, 106-112. [CrossRef] [PubMed]

157. Bots, M.L.; Visseren, F.; Evans, G.W.; Riley, W.A.; Revkin, J.H.; Tegeler, C.H.; Shear, C.L.; Duggan, W.T.; Vicari, R.M.; Grobbee, D.E.; et al. Torcetrapib and carotid intima-media thickness in mixed dyslipidaemia (RADIANCE 2 study): A randomised, double-blind trial. Lancet 2007, 370, 153-160. [CrossRef]

158. Barter, P.J.; Rye, K.-A.; Tardif, J.-C.; Waters, D.D.; Boekholdt, S.M.; Breazna, A.; Kastelein, J.J. Effect of Torcetrapib on Glucose, Insulin, and Hemoglobin A 1c in Subjects in the Investigation of Lipid Level Management to Understand its Impact in Atherosclerotic Events (ILLUMINATE) Trial. Circulation 2011, 124, 555-562. [CrossRef]

159. Clerc, R.G.; Stauffer, A.; Weibel, F.; Hainaut, E.; Perez, A.; Hoflack, J.-C.; Bénardeau, A.; Pflieger, P.; Garriz, J.M.; Funder, J.W.; et al. Mechanisms underlying off-target effects of the cholesteryl ester transfer protein inhibitor torcetrapib involve L-type calcium channels. J. Hypertens. 2010, 28, 1676-1686. [CrossRef]

160. Salahuddin, T.; Kittelson, J.; Tardif, J.-C.; Shah, P.K.; Olsson, A.G.; Nicholls, S.J.; Leitersdorf, E.; Leiter, L.A.; Kallend, D.; Black, D.M.; et al. Association of high-density lipoprotein particle concentration with cardiovascular risk following acute coronary syndrome: A case-cohort analysis of the dal-Outcomes trial. Am. Hear. J. 2020, 221, 60-66. [CrossRef]

161. Bagdade, J.; Barter, P.; Quiroga, C.; Alaupovic, P. Effects of Torcetrapib and Statin Treatment on ApoC-III and Apoprotein-Defined Lipoprotein Subclasses (from the ILLUMINATE Trial). Am. J. Cardiol. 2017, 119, 1753-1756. [CrossRef] [PubMed]

162. Barter, P.J.; Nicholls, S.J.; Kastelein, J.J.P.; Rye, K.-A. Is Cholesteryl Ester Transfer Protein Inhibition an Effective Strategy to Reduce Cardiovascular Risk? Circulation 2015, 132, 423-432. [CrossRef] [PubMed]

163. Noto, D.; Cefalu', A.B.; Averna, M.R. Beyond Statins: New Lipid Lowering Strategies to Reduce Cardiovascular Risk. Curr. Atheroscler. Rep. 2014, 16, 1-10. [CrossRef] [PubMed]

164. Woudberg, N.; Pedretti, S.; Lecour, S.; Schulz, R.; Vuilleumier, N.; James, R.W.; Frias, M.A. Pharmacological Intervention to Modulate HDL: What Do We Target? Front. Pharmacol. 2018, 8. [CrossRef] [PubMed] 